\title{
Effect of Climate Change on Potential Groundwater Recharge in the Dry Zone of Sri Lanka
}

\author{
Roshan P. de Silva ${ }^{1 *}$ \\ ${ }^{1}$ Department of Civil Engineering, School of Architecture, Design \& Built Environment, \\ Nottingham Trent University, Nottingham, Burton Street, NG1 4BU, UK.
}

Author's contribution

The sole author designed, analyzed and interpreted and prepared the manuscript.

Article Information

DOI: $10.9734 / B J E C C / 2015 / 16018$

Original Research Article

Received $31^{\text {st }}$ December 2014
Accepted $4^{\text {th }}$ February 2015
Published $17^{\text {th }}$ April 2015

\section{ABSTRACT}

Groundwater is still an important water source for many parts of the world, especially in countries such as Sri Lanka, because, despite a huge government investment to divert some of the rivers to dry areas, there are many areas which this river water cannot reach, and hence a large number of people depend on groundwater for their basic water requirements. The effects of climate change are evident in all parts of the world which include significant weather pattern changes, effect on fauna and flora, see level changes etc. Groundwater recharge, which results mostly from rainfall in many areas of the dry zone, will therefore be different from what they are now. This study looks at the possible effects of climate change on the estimates of potential groundwater recharge in the dry zone of Sri Lanka.

The study locations chosen were Angunakolapellessa, Mahalllupallama and Kalpitiya, where estimates of recharge were obtained with a soil water balance model, programmed on a spreadsheet. The model was validated with estimates of recharge obtained by different workers at different locations including Sri Lanka. Parameters of (rainfall and evapotranspiration) generated from a Regional Climate Model (PRECIS)were inputted to the model both for the 1961-89 (baseline) as well as for the 2071-99 (generated) periods, giving estimates of recharge for the periods 1961-89 and 2071-99.

The results show that the current estimates of recharge are likely to be reduced by $20-40 \%$ in the three study locations. The possible effects of such changes in recharge estimates and possible action to mitigate these possible effects of high/low estimates of recharge are also discussed.

Keywords: Groundwater recharge; climate change; dry zone of Sri Lanka.

*Corresponding author: Email: roshan.desilva@ntu.ac.uk; 


\section{INTRODUCTION}

The importance of groundwater for a country like Sri Lanka is well documented and well known $[1,2]$. As piped water supply is not available in many parts of the country except for a few cities and towns, people in most areas, especially in the dry zone, depend on dug wells, agro wells or occasionally a bored deep well (locally known as a tube well) for their water requirements, unless a canal (which might not be flowing at all times) or a reservoir is available in the near vicinity. As at 2005 , about $70 \%$ of the population in the country depended on groundwater for their water needs and more than $25 \%$ of the piped water supply came from groundwater [3]. To harness the groundwater resource sustainably, one of the most important parameters which cannot be overlooked is the rate at which the water table is replenished (mostly from precipitation) known as the groundwater recharge rate.

Due to the overwhelming evidence like global temperature increase, extreme climatic conditions including heavy bursts of precipitation in a shorter time and desertification in many parts of the world, melting of ice caps in the arctic and extinction of many animal and plant species, most people now believe that the climate change is real. In the last century, the temperature of the earth rose by about $0.6^{\circ} \mathrm{C}$ [4] and it is expected to rise between 1.4 to $5.8^{\circ} \mathrm{C}$ by 2100 due to the emission of greenhouse gasses [5] and the temperature in Sri Lanka is said to increase by $0.9-4.0^{\circ} \mathrm{C}$ by 2100 over the baseline period (1961-1990) temperature [6]. Worldwide, there have been many studies related to various aspects of climate change on groundwater $[7,8,9,10]$ and a relatively fair number of studies on the effect of climate change on the groundwater recharge $[11,12,13,14,15,16,17,18]$. However, the $4^{\text {th }}$ report of IPCC [19] states that "there has been very little research on the impact of climate change on groundwater and that the few studies of climatic impacts on groundwater for various aquifers show very site specific results". This may be because, instinctively, one might tend to think that these groundwater resources are hidden and hence protected from the vagaries of weather, but, a little thought will enable anyone to imagine the scary effects of such a scenario. Studies on the effects of climate change on any of the aspects of groundwater in Sri Lankan have been scarce $[6,20,21]$ and almost non-existent in reporting the effects on the estimates of groundwater recharge. In fact, one of the important research areas identified at the National Seminar on Groundwater Governance in Sri Lanka [22] is the "Effects on groundwater due to climate changes".

Most of the work reported on the effect of climate change on groundwater recharge suggests a decline in recharge rates over the coming years. Eckhardt and Ulbrich [12] from their study on the Dill catchment in south east Germany, suggest that recharge rates could be as low as $50 \%$ of the existing values, whereas Herrera-Pantoja and Hiscock [13] from their study in three locations (Coltishall, Gatwick and Paisley)in UK conclude that recharge rates could be as low as $88 \%$ of the existing rates at least for Paisley and in general it will be declining with the increase of temperatures. Thampi and Raneesh [18], from their study in Chaliyar river basin in Kerala, South India forecast a reduction of recharge by 4 - $7 \%$ by $2071-2100$. They have used the regional climate model (RCM) PRECIS to predict the future climate and then fed these into a hydrologic model to estimate the recharge. Dawes et al. [17], have used a general climate model (GCM) and MODFLOW respectively to estimate climate and recharge and concludes that recharge estimates could be as low as 60$99 \%$ in the Swan coastal plain in South West Australia. Jackson et al. [16] have used 13 GCMs to estimate the climate in 2080 in Central Southern England and have concluded that the recharge estimates could be decreased by $26 \%$ or increase by $31 \%$ depending the GCM used. However ten of the GCMs predict an increase in recharge and they are of the view that where possible as many climate models must be used to arrive at the climate in order to get realistic results. However, Nyenje and Batelaan [15] found the estimates of recharge to increase by $20-100 \%$ for the period $2020-2080$ for the Upper Ssezibawa catchment in Uganda and Jyrkama and Sykes [11] from their study in the Grand River watershed in south western Ontario in Canada, predict that recharge rates could be increasing by as much as $100 \mathrm{~mm} /$ year over the next 40 years, as warmer winter temperatures reduce the amount of ground frost and allows more water to infiltrate resulting in increased groundwater recharge rates.

The studies of climate change on any aspects of groundwater in Sri Lanka include the study by Ranjan et al. [20] where they have estimated the effects of salt water intrusion due to climate change on coastal aquifers in Sri Lanka assuming a sharp interface of sea and fresh water model. Eriygama et al. [6] have looked at 
the climate change effects on water resources with special emphasis on agriculture and developed a climate change vulnerability index (CCVI) and concludes that this index is high in the typical farming districts such as Anurdhapura, Badulla and NuwaraEliya resulting in adverse effects of climate change in these districts. In their study, de Silva et al. [21] have estimated that the average annual paddy water requirement is likely to go up by about $23 \%$ in 2050 due to the climate change effects as they estimate from a global climate model ( $\mathrm{HadCM} 3)$ that the rainfall is likely to reduce by $9-17 \%$ and potential evapotranspiration is likely to increase by $3.5 \%$. It is noted here that unlike in the global scenario where some studies have found an increase in groundwater (recharge) whilst others show a decrease, in the Sri Lankan studies, all point towards a decrease in the groundwater resource. However, none of the above studies for Sri Lanka have directly attempted to see the effects of climate change on estimates of groundwater recharge.

In this context, this study was carried out to investigate the possible effect of climate change on the estimates of groundwater recharge rates in the dry zone of Sri Lanka, which as said before is very important for a country like Sri Lanka as $70 \%$ people depend on it and also because groundwater recharge rate is possibly the most important parameter one needs to know to develop / use the groundwater without any adverse effects.

\section{MATERIALS AND METHODS}

The locations chosen for this study were Angunakolapellessa, Mahallluppallama and Kalpitiya in the dry zone of Sri Lanka (Fig. 1). These locations were chosen because of the readily availability of required data as some of the research centres for dry zone agriculture are situated in these locations.

Tables 1 and 2 below show the climatic, vegetation and soil data for the study area.

The methodology adopted in this study is as follows:

1. A simple soil water balance model (Fig. 2) was developed to estimate groundwater recharge in the dry zone of Sri Lanka after considering all the important processes of the hydrological cycle which are likely to be important in this zone. The model was converted to a spreadsheet model on a computer so that daily calculations and estimate for daily recharge is done quickly and easily. Processes such as interception of rainfall by vegetation and runoff as well as flow through cracks in the clayey soil (ie preferential flow) were included along with rainfall, run off and evapotranspiration in the model formed and programmed on a spreadsheet. Full details of the module and explanations as to why a particular sub model was used for a particular process are given in de Silva [23]. The time step for this model was one day as is recommended for optimum use of soil water balances $[24,25]$. Rainfall and pan evaporation data were obtained from the Department of Meteorology in Colombo, Sri Lanka and from the Regional Dry Zone Research Centres at Angunakolapellessa and Mahallupallama. Pan evaporation data were converted to evapotranspiration data by multiplying with an appropriate pan coefficient.

2. By careful consideration of the climate, vegetation and soils the required variables and parameters for the soil water balance was obtained. Full details of this analysis and the procedure involved are available in de Silva [23].

3. Laboratory work was carried out to determine the field capacity and permanent wilting point of the root zone soils as these two parameters were inputs in the said soil water balance model.

4. This model was tested for accuracy using data and recharge estimates and experimentally determined soil moisture deficit data as explained in de Silva [23].

5. The validated model was then used to estimate recharge with both baseline data of rainfall and potential evapotranspiration for the baseline period (1961-89) and for the generated data period (2071-99). This generated data was obtained by courtesy of the PRECIS [26] Regional Climate Modelling System through Dr (Mrs) Savita Patwardhan, Indian Institute of Tropical Meteorology, Pashan Rd, Panchawati, Pashan, Pune, Maharashtra 411008, India and Dr. R. Jagannathan, Professor of Agronomy, Department of Agronomy, Tamil Nadu Agricultural University, Coimbatore-641003 (personal communication, 2011-2012). Figs. 3 \& 4 show the baseline and generated rainfall and evapotranspiration respectively for the three study locations. 
6. The estimated recharge both for the

then compared to see the effect of climate baseline period and generated period was

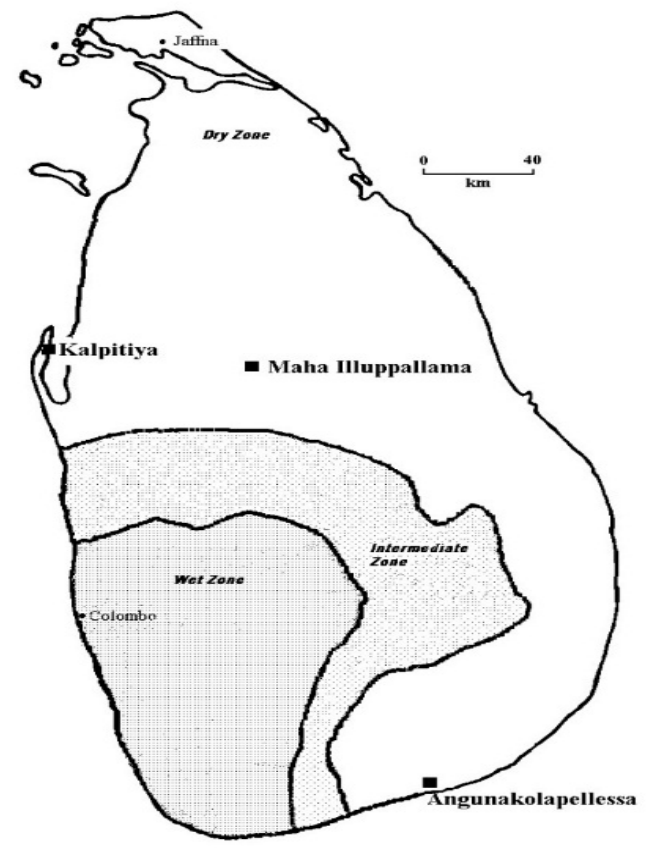

Fig. 1. Study locations in the dry zone of Sri Lanka

Table 1. Climate data for study locations

\begin{tabular}{lllll}
\hline Study location & \multicolumn{2}{c}{$\mathbf{1 9 6 1 - 8 9}$ (Baseline) } & \multicolumn{2}{c}{ 2071-99 (Generated) } \\
\cline { 2 - 5 } & $\begin{array}{l}\text { Mean } \\
\text { annual rain } \\
(\mathbf{m m} / \mathbf{y})\end{array}$ & $\begin{array}{l}\text { Mean annual pan } \\
\text { evaporation } \\
(\mathbf{m m} / \mathbf{y})\end{array}$ & $\begin{array}{l}\text { Mean annual } \\
\text { rain (mm/y) }\end{array}$ & $\begin{array}{l}\text { Mean annual pan } \\
\text { evaporation } \\
(\mathbf{m m} / \mathbf{y})\end{array}$ \\
\hline $\begin{array}{l}\text { Angunakolapellessa } \\
\text { (LAT: 6.164, LON: 80.898) }\end{array}$ & 951 & 1547 & 1121 & 1613 \\
\hline $\begin{array}{l}\text { Mahallluppallama } \\
\text { (LAT: 8.233, LON: } 79.767)\end{array}$ & 1195 & 1682 & 1265 & 1858 \\
\hline $\begin{array}{l}\text { Kalpitiya } \\
\text { (LAT: 6.249, LON: 80.767) }\end{array}$ & 955 & 1823 & 916 & 2052 \\
\hline
\end{tabular}

Table 2. Soil and vegetation data for study locations

\begin{tabular}{|c|c|c|c|c|c|c|}
\hline Study location & $\begin{array}{l}\text { Root zone } \\
\text { depth }(m)\end{array}$ & $\begin{array}{l}\text { Field } \\
\text { capacity } \\
(\%)\end{array}$ & $\begin{array}{l}\text { Permanent } \\
\text { wilting point } \\
\text { (\%) }\end{array}$ & Soil & Vegetation & Topography \\
\hline $\begin{array}{l}\text { Angunakolapellessa } \\
\text { (LAT: 6.164, LON: } \\
\text { 80.898) }\end{array}$ & 0.95 & 20.2 & 12 & $\begin{array}{l}\text { Sandy } \\
\text { Clay } \\
\text { Loam }\end{array}$ & $\begin{array}{l}\text { Dense } \\
\text { Shrub } \\
\text { jungle }\end{array}$ & $\begin{array}{l}\text { Flat- } \\
\text { undulating }\end{array}$ \\
\hline $\begin{array}{l}\text { Mahallluppallama } \\
\text { (LAT: 8.233, LON: } \\
\text { 79.767) }\end{array}$ & 1.17 & 20.9 & 11 & $\begin{array}{l}\text { Loamy } \\
\text { Sand }\end{array}$ & jungle & Flat \\
\hline $\begin{array}{l}\text { Kalpitiya } \\
\text { (LAT: 6.249, LON: } \\
80.767 \text { ) }\end{array}$ & 1.5 & 14 & 4 & Sand & $\begin{array}{l}\text { Sparse } \\
\text { Jungle }\end{array}$ & Flat \\
\hline
\end{tabular}




\section{RESULTS AND DISCUSSION}

The Soil Water Balance model developed, was validated with data from different locations around the world as shown in Table 3.

The SWB model was also validated with recharge estimated for Angunakolapellessa for the period 1961 - 1989 which is $98 \mathrm{~mm}$ /year and this compares well with other published results for the same area by different methods (e.g. Dharmasiri and Dharmawardena, [31], estimates a recharge of $59 \mathrm{~mm} /$ year using tritium profiling for this study area; Seneviratne [32] estimates recharge in the Walave basin to vary between 20 - $450 \mathrm{~mm}$ /year from chloride profiling).
The estimates of recharge for the baseline period (1961-89) and for the period 2071-99 for the three study location are shown in Tables 4 and 5 shows the yearly estimates of recharge for the three locations both for the baseline and generated periods.

Fig. 6 shows the daily distribution of estimates of groundwater recharge for the three locations both for the baseline and generated periods.

Fig. 7 shows the estimates of annual recharge for the three locations both for the baseline and generated periods.

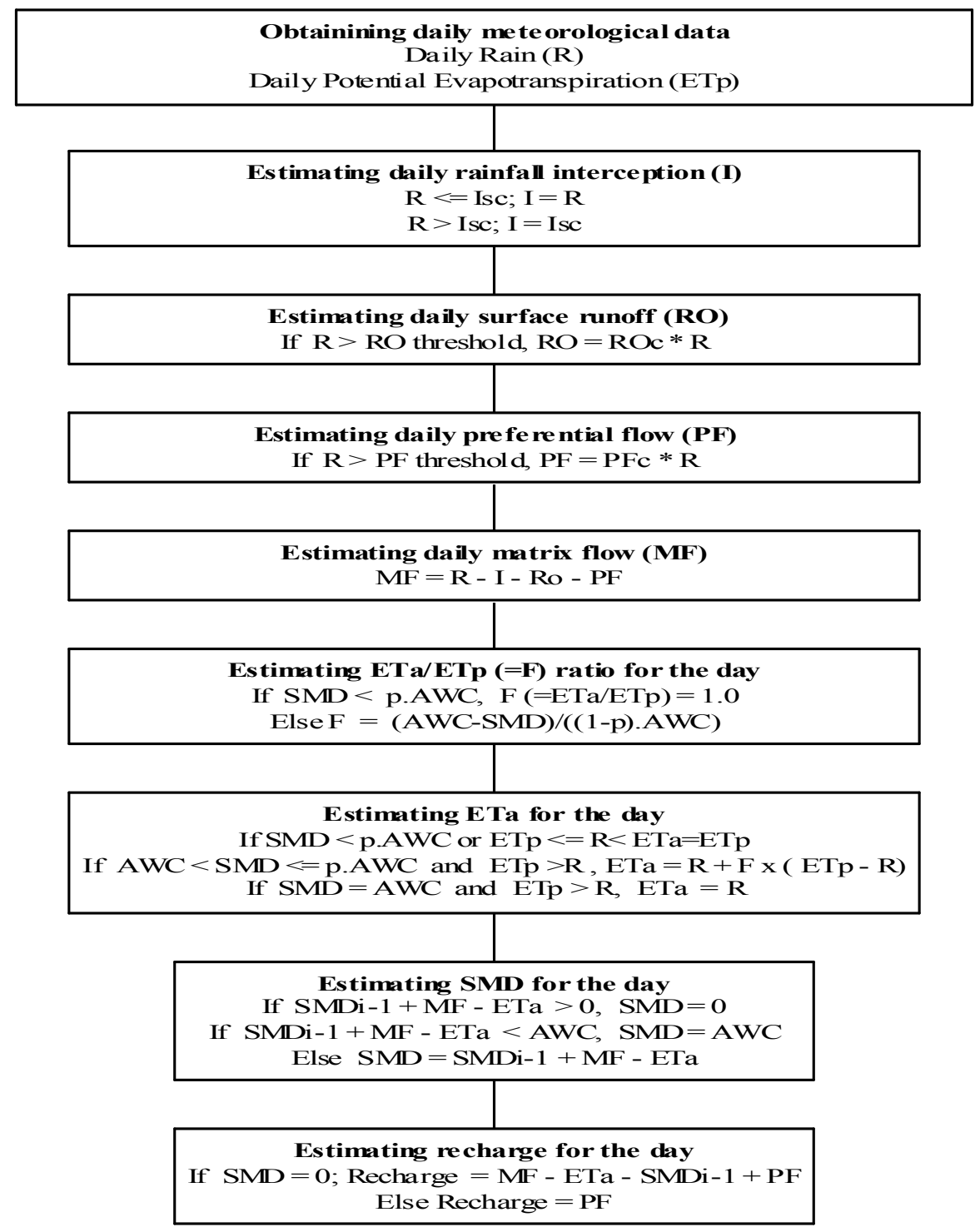

Fig. 2. Flow chart of the soil water balance model suitable for the dry zone of Sri Lanka 


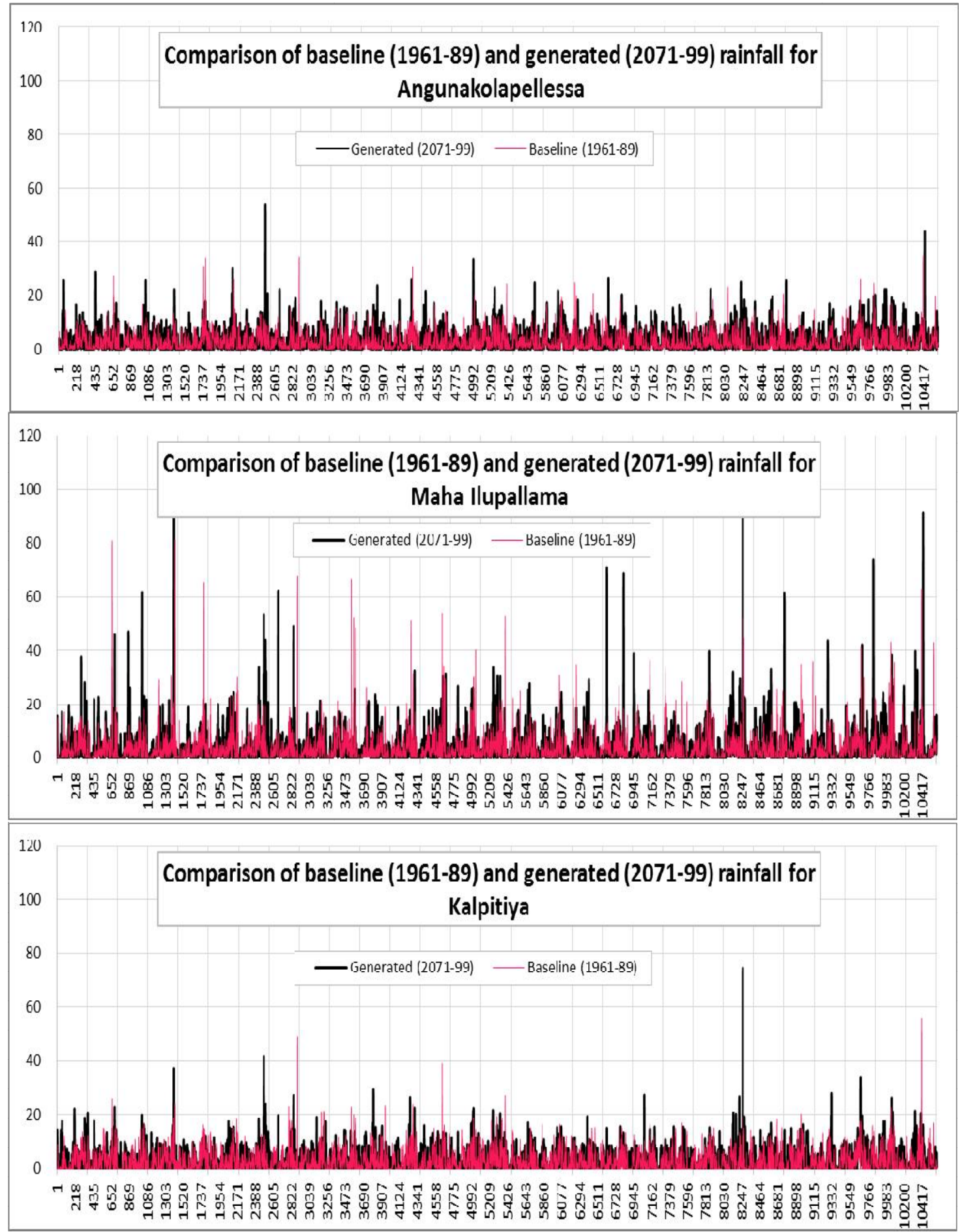

Fig. 3. A graphical illustration of baseline (1961-89) and generated (2071-99) rainfall for the three study locations (NOTE: Vertical axis - Rainfall $(\mathrm{mm})$ and horizontal axis - Time (days) 

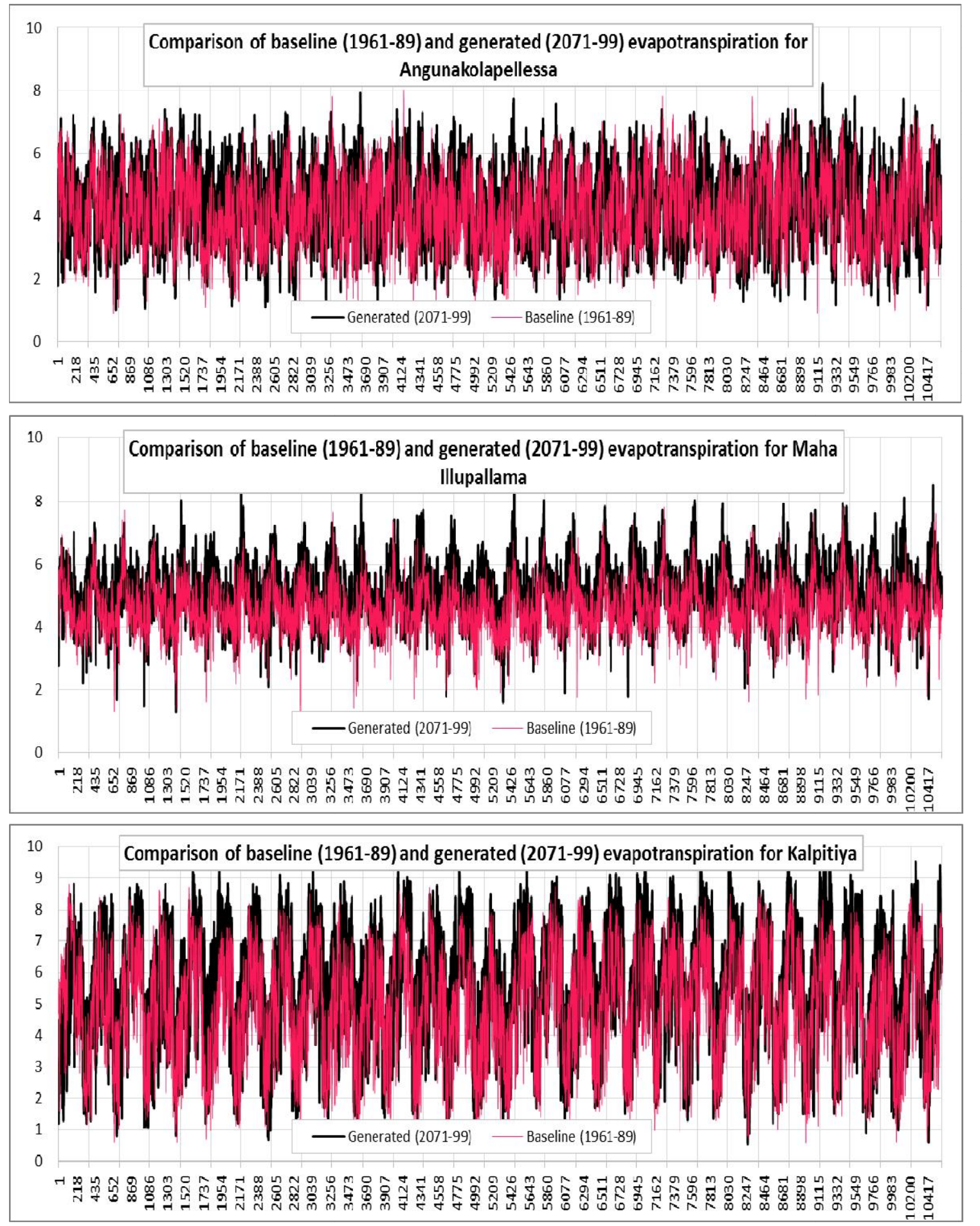

Fig. 4. A graphical illustration of baseline (1961-89) and generated (2071-99) evapotranspiration for the three study locations (NOTE: Vertical axis - Rainfall $(\mathrm{mm})$ and horizontal axis Time (days) 
Table 3. Validation of the soil water balance model developed

\begin{tabular}{|c|c|c|c|c|c|c|}
\hline Location & $\begin{array}{l}\text { Mean annual } \\
\text { Precipitation } \\
(\mathrm{mm} / \mathrm{y})\end{array}$ & $\begin{array}{l}\text { Mean } \\
\text { annual } \\
\text { ETp } \\
(\mathrm{mm} / \mathrm{y})\end{array}$ & $\begin{array}{l}\text { Available } \\
\text { estimate and } \\
\text { method this } \\
\text { estimate was } \\
\text { obtained }\end{array}$ & Source & $\begin{array}{l}\text { Soil water } \\
\text { balance } \\
\text { model(use } \\
\text { d in this } \\
\text { study) } \\
\text { estimate }\end{array}$ & $\begin{array}{l}\text { Time steps } \\
\text { and duration } \\
\text { of SWB }\end{array}$ \\
\hline $\begin{array}{l}\text { Ngwazi, } \\
\text { Tanzania }\end{array}$ & 630 & 1397 & $\begin{array}{l}\text { Soil moisture } \\
\text { deficit (see Fig. 6) } \\
\text { from field } \\
\text { measurement (on } \\
15 \text { Nov the SMD } \\
\text { measured was } \\
338 \mathrm{~mm} \text { ) }\end{array}$ & [27] & $\begin{array}{l}\text { See Fig. } 5 \\
\text { (on } 15 \text { Nov } \\
1989 \text { the } \\
\text { SMD } \\
\text { predicted } \\
\text { was } 335 \\
\mathrm{~mm} \text { ) }\end{array}$ & $\begin{array}{l}\text { Daily for } 245 \\
\text { days (1 Apr } 89 \\
-1 \text { Dec } 89, \\
\text { both days } \\
\text { inclusive) }\end{array}$ \\
\hline $\begin{array}{l}\text { Nguru, } \\
\text { Nigeria }\end{array}$ & 463 & 2090 & $\begin{array}{l}\text { Recharge, } 30-60 \\
\mathrm{~mm} / \mathrm{y} \text { from } \\
\text { groundwater flow } \\
\text { modelling and } \\
\text { chloride method }\end{array}$ & $\begin{array}{l}\text { [28] and Carter } \\
\text { (1996) personal } \\
\text { communication }\end{array}$ & $29 \mathrm{~mm} / \mathrm{y}$ & $\begin{array}{l}\text { Daily for } 11 \\
\text { years (1965 - } \\
1975, \text { both } \\
\text { years } \\
\text { inclusive) }\end{array}$ \\
\hline Silsoe, UK & 560 & 721 & $\begin{array}{l}\text { Recharge, 94-183 } \\
\mathrm{mm} / \mathrm{y} \text { from a SWB } \\
\text { and } \\
\text { Recharge, } 168 \\
\mathrm{~mm} / \mathrm{y} \text { from } \\
\text { chloride method }\end{array}$ & $\begin{array}{l}{[29]} \\
{[30]}\end{array}$ & $121 \mathrm{~mm} / \mathrm{y}$ & $\begin{array}{l}\text { Daily for } 30 \\
\text { years (1962 - } \\
1991, \text { both } \\
\text { years } \\
\text { inclusive) }\end{array}$ \\
\hline
\end{tabular}

Rain, Experimentally observed \& SWB estimated SMD at Ngwazi Tea Research Unit in Tanzania, 1989

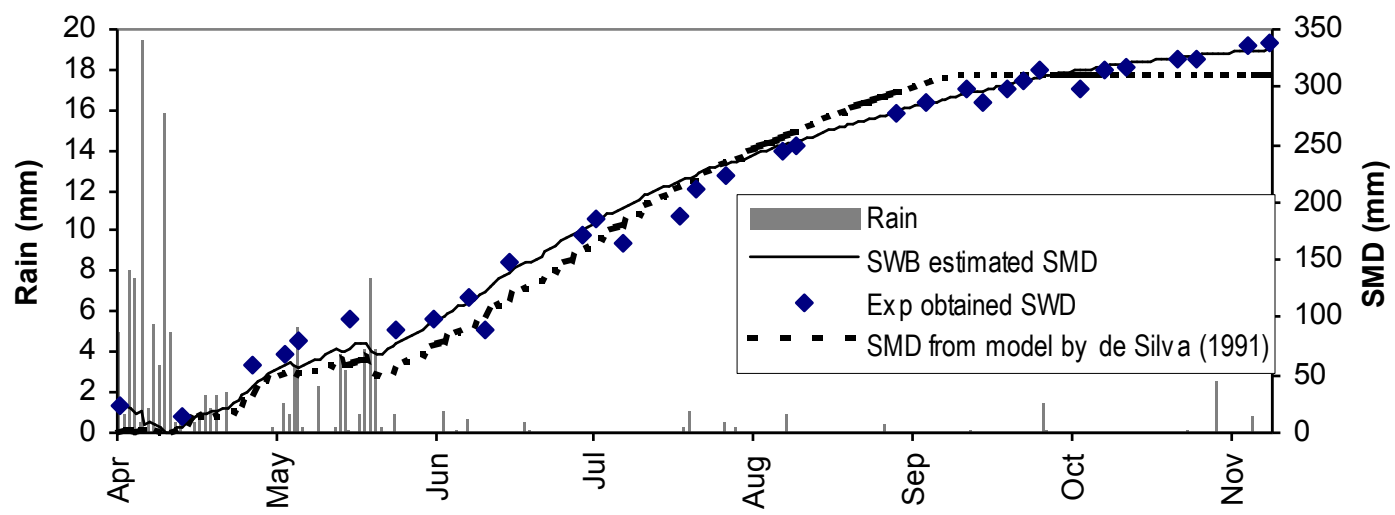

Fig. 5. Experimental soil moisture deficit and soil water budget model estimated soil moisture deficit

Table 4. Estimates of average annual recharge for the baseline (1961-89) and generated (2071-99) periods for the three study locations

\begin{tabular}{llll}
\hline & Angunakolapellessa & Mahallluppallama & Kalpitiya \\
\hline $1961-89$ & 98 & 126 & 79 \\
$2071-99$ & 80 & 78 & 65 \\
\% change from 1961-89 & $-18 \%$ & $-38 \%$ & $-18 \%$ \\
to 2071-99 & & & \\
\hline
\end{tabular}


Table 5. Estimates of yearly recharge for the baseline (1961-89) and generated (2071-99) periods for the three study locations

\begin{tabular}{|c|c|c|c|c|c|c|}
\hline \multicolumn{7}{|c|}{ Recharge (mm/y) } \\
\hline \multirow[t]{2}{*}{ Year } & \multicolumn{2}{|c|}{ Angunakolapellessa } & \multicolumn{2}{|c|}{ Mahallluppallama } & \multicolumn{2}{|c|}{ Kalpitiya } \\
\hline & 1961-89 & $2071-99$ & $1961-89$ & 2071-99 & 1961-89 & 2071-99 \\
\hline 1 & 88 & 52 & 120 & 37 & 86 & 34 \\
\hline 2 & 80 & 18 & 179 & 50 & 71 & 29 \\
\hline 3 & 49 & 27 & 79 & 69 & 35 & 38 \\
\hline 4 & 45 & 6 & 106 & 163 & 73 & 77 \\
\hline 5 & 221 & 9 & 184 & 29 & 168 & 1 \\
\hline 6 & 120 & 29 & 131 & 75 & 107 & 47 \\
\hline 7 & 108 & 128 & 118 & 82 & 15 & 101 \\
\hline 8 & 86 & 52 & 123 & 42 & 66 & 67 \\
\hline 9 & 76 & 5 & 83 & 35 & 116 & 3 \\
\hline 10 & 113 & 30 & 230 & 42 & 112 & 11 \\
\hline 11 & 56 & 83 & 68 & 39 & 17 & 38 \\
\hline 12 & 126 & 57 & 105 & 27 & 85 & 22 \\
\hline 13 & 68 & 14 & 159 & 81 & 91 & 5 \\
\hline 14 & 71 & 166 & 110 & 40 & 84 & 195 \\
\hline 15 & 148 & 85 & 136 & 152 & 77 & 8 \\
\hline 16 & 73 & 42 & 111 & 56 & 13 & 4 \\
\hline 17 & 102 & 190 & 79 & 97 & 71 & 86 \\
\hline 18 & 97 & 6 & 92 & 75 & 25 & 1 \\
\hline 19 & 84 & 167 & 112 & 95 & 12 & 101 \\
\hline 20 & 67 & 39 & 95 & 75 & 21 & 3 \\
\hline 21 & 39 & 6 & 142 & 19 & 18 & 3 \\
\hline 22 & 118 & 110 & 179 & 45 & 136 & 103 \\
\hline 23 & 104 & 154 & 116 & 157 & 26 & 227 \\
\hline 24 & 82 & 159 & 109 & 106 & 20 & 139 \\
\hline 25 & 58 & 55 & 109 & 48 & 91 & 48 \\
\hline 26 & 73 & 97 & 80 & 34 & 89 & 69 \\
\hline 27 & 304 & 392 & 171 & 120 & 144 & 306 \\
\hline 28 & 98 & 100 & 210 & 239 & 193 & 74 \\
\hline 29 & 94 & 50 & 134 & 119 & 226 & 49 \\
\hline
\end{tabular}

From the results presented, it can be seen that the estimated recharge rates are likely to decrease in the dry zone during the period 207199, compared to the baseline period (1961-99). On average, the decreases are about $20 \%$ for Angunakolapellessa and Kalpitiya and about $40 \%$ for Mahalllupallama. Also the yearly values show significant differences for the two periods (as seen in Table 5 above) and in certain periods (eg. years 4, 5 and 6 for Angunakolapellessa) the recharge values are significantly low for few consecutive years in the 2071-99 period and these very low recharge values will have drastic effects on humans, animals and agriculture, as the amount of water reaching the water table will be minimal for a few consecutive years, compounding the problems. The reduced estimates of recharge are in agreement with most of the studies for different parts of the world $[12,13]$. They are also in agreement with the reported studies of climate change on rainfall / groundwater in Sri Lanka where all the documented literature points to a decrease in rainfall / recharge $[6,20,21]$.
However, there are certain years (eg years 4 and 28 for Angunakolapellessa) where the estimates of recharge for the generated period are higher, compared with that of the baseline period. The effects of increased recharge include increased availability of groundwater for consumption, but, for most parts of the dry zone of Sri Lanka, this is not likely to be of much benefit as most of the dry zone is underlain by crystalline hard rock and storage of this increased recharge will not be possible in most areas except where cracks and fissures are available in the hard rock. Undesirable effects of increased recharge include increased salinity rendering the area not suitable for agriculture, upwards movement of the water table affecting crops/ forests with deep roots and possible increase in landslides especially in hilly areas. However, as pointed out, it is more likely for the recharge to decrease and the effects of decreasing recharge rates include, water tables lowering with associated ground subsidence, drying of wells and desertification. 

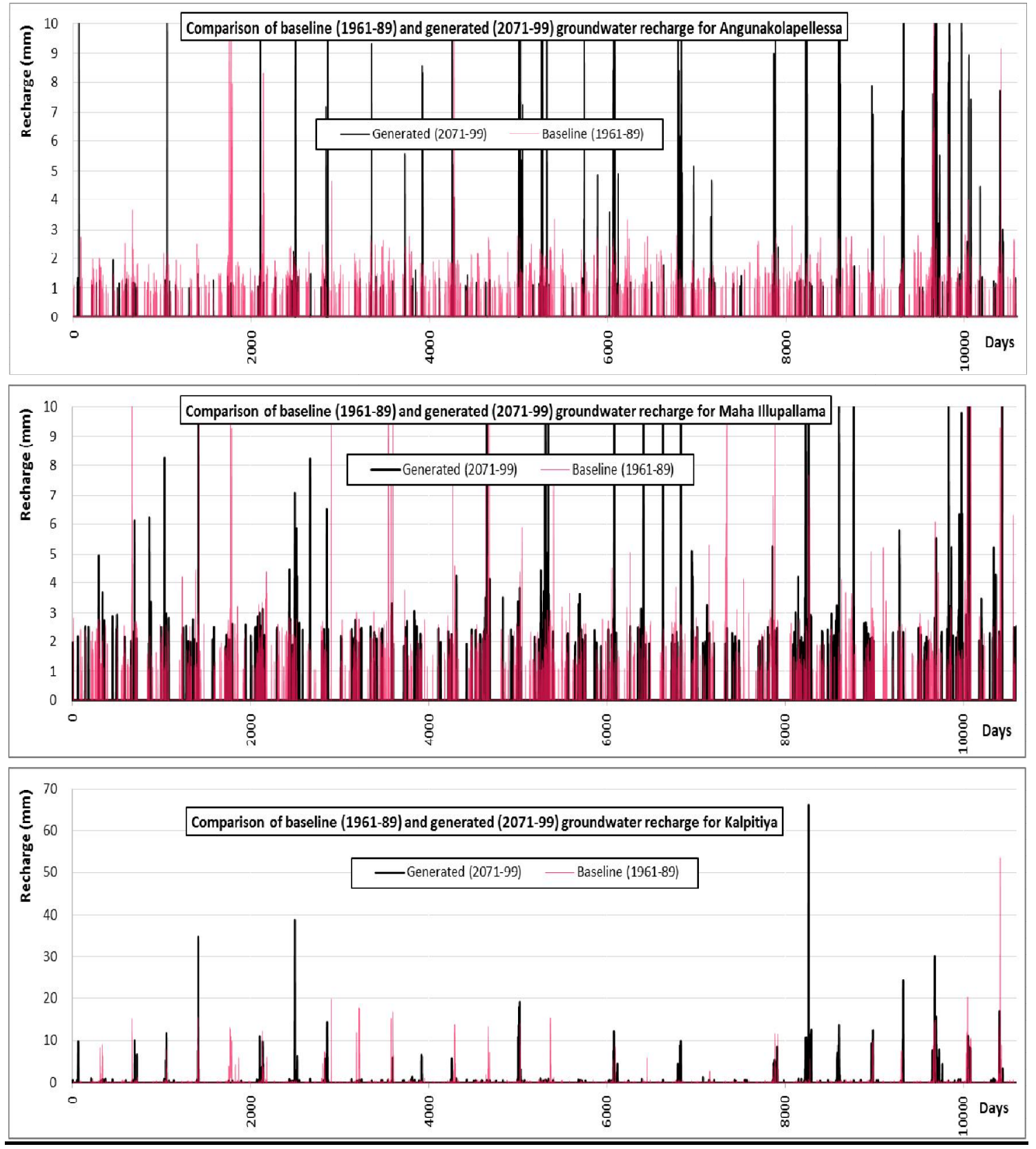

Fig. 6. Graphical representation of estimates of daily recharge for the baseline and generated periods for the three study locations

The approach used in the study may be improved by using more accurate models for estimating recharge. However, it is very likely that similar results are obtained, whatever models are used as the primary parameters that govern the recharge process (rainfall and evapotranspiration) are similar for all models which includes the model used in this study.
However as Jackson et al. [16] have shown, its best if the climate forecasts can be obtained with many RCMs and /or GCMs, which unfortunately was not possible in this study.

Another important consideration is the variation of rainfall / ET with time which is possible with climate change. It can be easily shown that even 
if the average annual values for rain / ET remain the same, the different variations of them throughout the year can cause significant effects on estimates of recharge. As daily values for rainfall, evapotranspiration and all other varying parameters were used, it is likely that the estimates of recharge from this study are closer to the true values compared to most studies where the time step has been a month or even some cases an year.
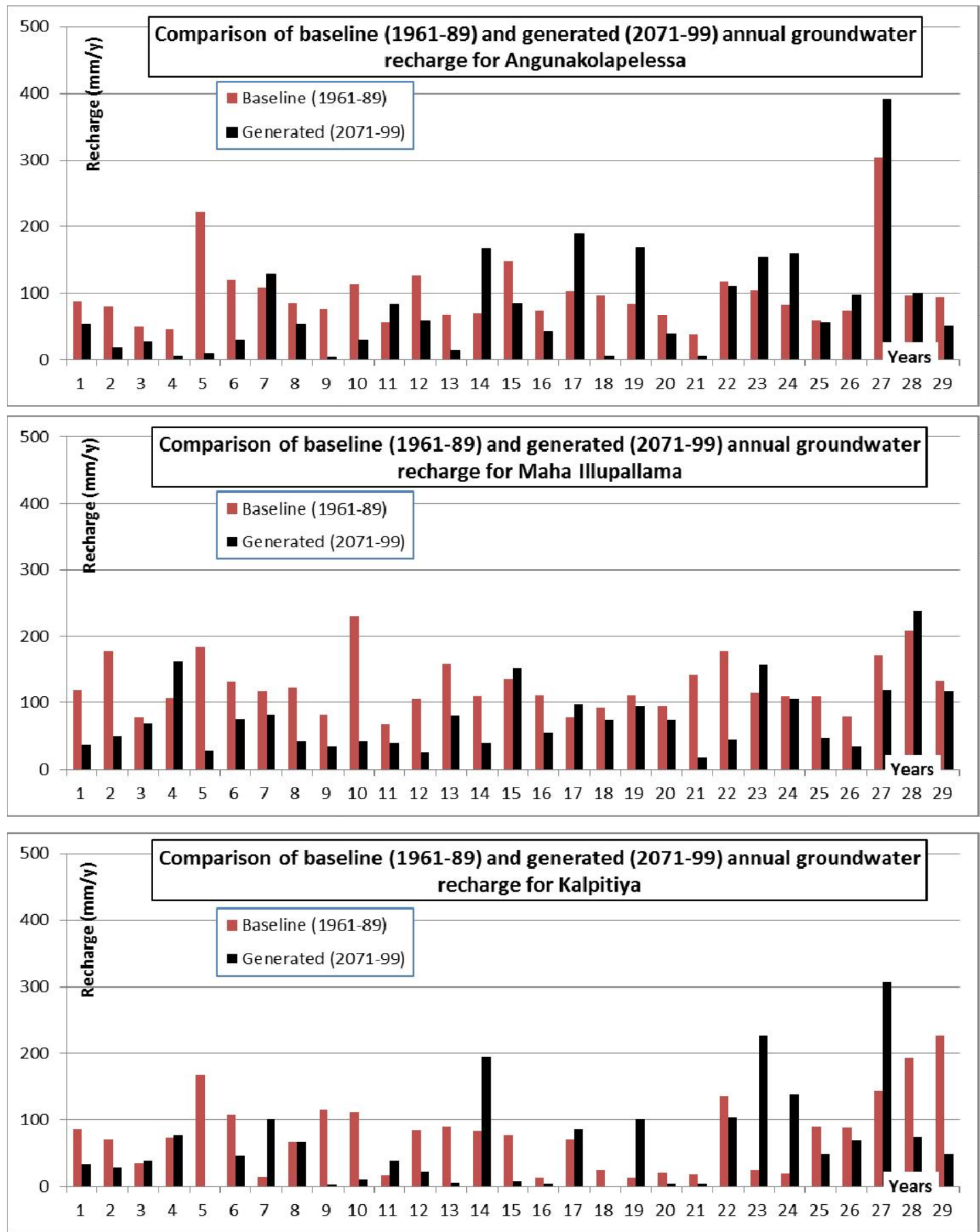

Fig. 7. Graphical representation of estimates of annual recharge for the baseline and generated periods for the three study locations 
This work, as most of the other work reported; assume that there is no change with any of the soil and vegetation parameters with climate change. However, as Holmann [33] indicated, it is very likely that this is unlikely to be the case as soils of the future may not have the same water infiltration properties. Other parameters considered for the model (ie, interception, runoff and preferential flow parameters) are likely to change as well as a result of climate change. If the results are to be more accurate, these effects also need to be considered and built into the model.

Due to the availability of resources, the present study was carried out only for three locations in the dry zone, but, need to be extended to a few other locations to arrive at a general conclusion for the dry zone. As Jackson et al. [16], from there study of 13 global climate forecasting models in UK found out, the potential groundwater recharge can vary from $-20 \%$ to + $31 \%$ depending on the climate forecasting model used. This is also supported by the work of Holmann et al. [34]. Further, it is also recommended that more accurate climate prediction models and a combination of such models be used in obtaining at least the two most important input variables of the model (i.e. rainfall and ET) in order to get more accurate estimates of recharge.

\section{CONCLUSION}

This study looked at the possibility of using climate data generated by a regional climate model (PRECIS) for the period 2071 - 99, in a simple soil water balance model to estimate the potential recharge rates for the same period in three locations in the dry zone of Sri Lanka. The following specific conclusions are arrived at, from this study.

(i) The forecasted estimates of recharge for the period 2071 - 99 are very likely to be reduced by an amount $20-40 \%$ compared to those of 1961 - 99 in the dry zone of Sri Lanka. However, as said before carrying out a similar study in more locations will enable in increasing the accuracy of this estimates as the above figures have been arrived at by studying only 3 locations (nevertheless they being representative of the average conditions in the dry zone of Sri Lanka).

(ii) The reduction in forecasted recharge is in good agreement with other studies which have looked at effects of climate change in groundwater / water resources in the dry zone of Sri Lanka.

(iii) This study is able to show the daily variations of forecasted groundwater recharge estimates in the dry zone of Sri Lanka, which has not been shown in any of the studies the author is aware.

(IV) The reduction of recharge is very likely due to the reduction in rainfall and increase in evapotranspiration as has been shown in other studies as well (de Silva et al. [21]).

\section{ACKNOWLEDGEMENTS}

The provision of climate data for the period 2071 -99 by $\mathrm{Dr}$ (Mrs) Savita Patwardhan, Indian Institute of Tropical Meteorology, Pashan Rd, Panchawati, Pashan, Pune, Maharashtra 411008, India and Dr. R. Jagannathan, Professor of Agronomy, Department of Agronomy, Tamil Nadu Agricultural University, Coimbatore641003, India using the high resolution regional climate model (PRECIS) developed by the Hadley Centre, UK Met Office is gratefully acknowledged.

\section{COMPETING INTERESTS}

Author has declared that no competing interests exist.

\section{REFERENCES}

1. Panabokke CR. Groundwater conditions in Sri Lanka: A geomorphic perspective. Colombo, Sri Lanka, National Science Foundation of Sri Lanka; 2007.

2. Sri Lanka National Water Development Report (2006), Sri Lanka Case Study: UNESCO world Water Assessment programme (UN-Water/WWAP/2006/11) Edited by K. A. U. S. Imbulana, N. T. S. Wijesekera, B. R. Neupane, ISBN: 9558395-01-3.

3. Herath Gemunu. (n.d.) Groundwater Management Groundwater Management Issues in Sri Lanka Issues in Sri Lanka. Last Accessed $10^{\text {th }}$ Jan 2015. Available:http://www.jst.go.jp/asts/asts t2/t hailand/200803/presentation/s4-2.pdf

4. IPCC. Climate Change 2001: Synthesis Report. A Contribution of Working Groups I, II, and III to the Third Assessment Report of the Intergovernmental Panel on Climate Change [Watson, R.T. and the Core 
Writing Team (eds.)]. Cambridge University Press, Cambridge, United Kingdom, and New York, NY, USA; 2001.

5. Dietrich-Egensteiner Will. A Beginner's Guide to the IPCC Climate Change Reports; 2013. Last Accessed $10^{\text {th }}$ Jan 2015.

Available:http://www.popularmechanics.co $\mathrm{m} /$ science/environment/climate-change/abeginners-guide-to-the-ipcc-climatechange-reports-15991849

6. Eriyagama N, Smakhtin V, Chandrapala L, Fernando K. Impacts of climate change on water resources and agriculture in Sri Lanka: A review and preliminary vulnerability mapping. Colombo, Sri Lanka: International Water Management Institute. 51p. (IWMI Research Report 135). 2010;51. DOI:10.3910/2010.211.

7. Davies EGR, Simonovic SP. Climate change and the hydrological cycle, proceedings of the $17^{\text {th }}$ Canadian HydroTechnical Conference, Edmonton, Alberta, Canada; 2005.

8. Scibek J, Allen DM. Comparing modelled responses of two high-permeability, unconfined aquifers to predicted climate change. Global and Planetary Change. 2006;50(1-2):50-62.

9. Scibek J, Allen DM, Cannon AJ, Whitfield $\mathrm{PH}$. Groundwater-surface water interaction under scenarios of climate change using a high-resolution transient groundwater model. Journal of Hydrology. 2007;333(2-4):165-181.

10. Goderniaux $P$, Brouyère $S$, Fowler $H J$, Blenkinsop $S$, Therrien $R$, Orban $P$, Dassargues A. Large scale surfacesubsurface hydrological model to assess climate change impacts on groundwater reserves. Journal of Hydrology. 2009;373(1-2):122-138.

11. Jyrkama MI, Sykes JF. The impact of climate change on spatially varying groundwater recharge in the grand river watershed (Ontario). Journal of Hydrology. 2007;338(3-4):237-250.

12. Eckhardta K, Ulbrichb U. Potential impacts of climate change on groundwater recharge and stream flow in a central European low mountain range. Journal of Hydrology. 2003;284:244-252.

13. Herrera-Pantoja M, Hiscock KM. The effects of climate change on potential groundwater recharge in Great Britain. Hydrological Processes. 2008;22(1):73-86. DOI: $10.1002 /$ hyp.6620.
14. Christine Rivard, Claudio Paniconi, Harold Vigneault, Diane Chaumont. A watershedscale study of climate change impacts on groundwater recharge (Annapolis Valley, Nova Scotia, Canada), Hydrological Sciences Journal. 2014;59:8:1437-1456. DOI: 10.1080/02626667.2014.887203.

15. Nyenje PM, Batelaan O. Estimating the effects of climate change on groundwater recharge and base flow in the upper Ssezibwa catchment, Uganda. Hydrol Sci J. 2009;54(4):713-726.

16. Jackson CR, Meister R, Prudhomme C. Modelling the effects of climate change and its uncertainty on UK Chalk groundwater resources from an ensemble of global climate model projections. J Hydrol. 2011;399:12-28.

17. Dawes $W$, et al. Modelling the effects of climate and land cover change on groundwater recharge in south-west Western Australia. Hydrology and Earth System Sciences. 2012;16:2709-2722.

18. Thampi SG, Raneesh KY. Impact of anticipated climate change on direct groundwater recharge in a humid tropical basin based on a simple conceptual model. Hydrological Processes. 2012;1655-1671.

19. IPCC. Climate Change 2007: The Physical Science Basis. Contribution of Working Group I to the Fourth Assessment Report of the Intergovernmental Panel on Climate Change [Solomon, S., D. Qin, M. Manning, Z. Chen, M. Marquis, K.B. Averyt M. Tignor and H.L. Miller (eds.)]. Cambridge University Press, Cambridge, United Kingdom and New York, NY, USA; 2007.

20. Priyantha Ranjan S, Kazama SO, Sawamoto Masaki. Effects of climate and land use changes on groundwater resources in coastal aquifers, Journal of Environmental Management. 2006;80:2535.

21. De Silva CS, Weatherhead EK, Knox JW, Rodriguez-Diaz JA. Predicting the impacts of climate change - A case study of paddy irrigation water requirements in Sri Lanka. Agricultural Water Management. 2007;93:19-29.

22. IWMI. Proceedings of the National Seminar on Groundwater Governance in Sri Lanka, Colombo, Sri Lanka, 15 August 2013. Colombo, Sri Lanka: International Water Management Institute (IWMI). 2013;134. DOI:10.5337/2014.201. 
23. De Silva RP. Estimating Groundwater Recharge in the Dry Zone of Sri Lanka with Special Emphasis on Spatial Variability. PhD Thesis, Silsoe College, Cranfield University, UK; 1996.

24. Howard KWF, Lloyd JW. The Sensitivity of Parameters in the Penman Evaporation Equations and Direct Recharge Balance. Journal of Hydrology. 1979;41:329-344.

25. De Silva RP. The effect of using weekly, 10 daily or monthly evapotranspiration data in a soil water balance model to estimate groundwater recharge in the dry zone of Sri Lanka. Journal of Environmental Hydrology, USA. 1999;7(4):1-11.

26. Met office, UK. (2011). The PRECIS Regional Climate Modelling System. Last Accessed $12^{\text {th }}$ Jan 2015.

Available:http://www.metoffice.gov.uk/preci s/

27. De Silva RP. A multi-layer soil water use model for tea. Unpublished MSc Thesis, Silsoe College, Cranfield University, UK; 1991.

28. Carter RC, Morgulis ED, Dottridge J, Agbo JU. Groundwater modelling with limited data: A case study in a semi-arid dunefield of Northeast Nigeria. Quarterly Journal of Engineering Geology. 1994;27:85-94.

29. Monkhouse RA. An assessment of the groundwater resources of the lower
Greensand in the Cambridge - Bedford Region. Water Resources Board, Reading, UK. Irving; 1974.

30. Irving WM. Chloride lon concentration as an aid to estimating recharge to the Woburn sands. Quarterly Journal of Engineering Geology. 1982;15:47-54.

31. Dharmasiri JK, Dharmawardena KG. Recharge measurements using tritium tracer at different sites in Sri Lanka. Interamerican Symposium on Isotope Hydrology, Bogota, Columbia; 1980.

32. Seneviratne AAAKK. Development of steady state groundwater flow model in lower Walawa Basin - Sri Lanka, Unpublished MSc Thesis, International Institute for Geo-information and Earth Observation, Enschede, The Netherlands; 2007.

33. Holman IP. Climate change impacts on groundwater recharge- uncertainty, shortcomings and the way forward? Hydrogeol J. 2006;14:637-647.

34. Holman IP, Allen DM, Cuthbert MO, Goderniaux P. Towards best practice for assessing the impacts of climate change on groundwater. Hydrogeology Journal. 2012;20(1):1-4.

(c) 2015 Silva; This is an Open Access article distributed under the terms of the Creative Commons Attribution License (http://creativecommons.org/licenses/by/4.0), which permits unrestricted use, distribution, and reproduction in any medium, provided the original work is properly cited.

Peer-review history:

The peer review history for this paper can be accessed here: http://www.sciencedomain.org/review-history.php?iid=1109\&id=10\&aid=8857 